\title{
Strategy Survively in the Middle of Uncertainity Pandemi Covid-19 Maritime Sector Business
}

\author{
Hadi Prasutiyon ${ }^{\mathrm{a}}$, R.O Saut Gurning ${ }^{\mathrm{b}}$ \\ ${ }^{a}$ Departement Of Marine Engineering and Marine Science, Hang Tuah University, Surabaya 60111, Indonesia. \\ ${ }^{\mathrm{b}}$ Departement Of Marine Engineering, Sepuluh Nopember Institute of Technology, Surabaya 60111, Indonesia.
}

\begin{abstract}
A B S T R A C T
The Covid-19 pandemic crisis of 2020, different from previous crisis / disasters, given the uncertainty, no one can predict or look ahead, when the end of this crisis is over. Global impact that touches almost all sectors and is directly related personally and family. Fast-moving events, we talk day by day, with a situation that is changing and unprecedented. This requires us to make policies, responses and rapid mitigation of impacts on shared covid-19. Management policies must reach the infrastructure, work and engagement sectors required to be fast and appropriate. In dealing with such situations, it is necessary to apply crisis management, so that the main things that must be prioritized can be found. The government is expected to provide fiscal incentives, especially to national companies, in the form of tax breaks, small loans, or other assistance. So that the company can survive to avoid layoffs and be able to rise again after going through this crisis.
\end{abstract}

Keywords: Regulation, covid-19 pandemic, survival strategy, reschedule, and innovation management.

Article History

Received 17 May 20

Received in revised form 1November 20

Accepted 12 November 20

\section{Introduction}

Indonesia is a maritime nation that is sovereign, independent, advanced, strong and capable of making positive contributions to the security and peace of the region and the world in accordance with national interests [1]. Industries supporting the smooth operation of the national logistics and logistics are very important in helping the national defense power, economic development, and the development of other industrial sectors such as the steel industry, the electronics industry, and the machinery industry [2]. These sectors are labor-intensive, capital-intensive, technology-intensive, and encourage global competitiveness, both in the sector, sea transportation, fishery, cruise / tourism, and defense [3]. Maritime infrastructure, among others, ports, shipyards / shipping industry, and ships / shipping, with the covid pandemic 19, must make a new strategy, both in marketing, finance, where this field is the breath of the company so it must immediately act for new negotiations / re, especially in terms of billing and strengthening cash flow because their customers are mostly shipping companies, besides that they must prepare company obligations for existing claims in the form of salaries, THRs, and obligations to other parties such as contractors, vendors or suppliers, so that This requires a strategy of how the company can provide security and comfort for all stakeholders including the fate of the company after the Covid 19 pandemic period is over [3][1][2].

\footnotetext{
* Corresponding author. Phone : +0-000-000-0000 ; fax: +0-000-000-0000

E-mail address: author@institute.xxx .
}

In normal conditions the need for raw materials can always be met in accordance with needs, the stages of work both regarding the process of work involving resources, financing, methods and technology can also adjust to the schedule that has been set [3][2]. Products can be driven according to the wishes of both the owner and client / customer who have fulfilled the design and legalization aspects. The results of the work can be delivered in accordance with the schedule that has been set. But with the covid pandemic 19, things are slowing down, according to the government's recommendations, companies are suddenly required to take steps to adjust and on the other hand the worsening condition of the global market [5][13][20]. This is forcing companies to negotiate corporate loans to banks, collect accounts receivable faster than promised, renegotiate debts to suppliers, maximize bonds wisely, and revise corporate financial planning, this is the condition that forces companies to make strategy to survive in various ways and realize the achievement of the company will not be achieved in accordance with those set [7][10]. All company components must be united make steps for the safety of the company [3][4]. Prerequisites for the existence of the shipbuilding industry in particular, also take steps to change the patterns of marketing strategies from online and offline to all online-based, also to conduct financial strategies by renegotiating work that if it is not met according to the schedule that has become an agreement, doing bill of receivables as soon as possible with a balance of progress and guarantee of settlement, this is done for the sake of creating a good corporate financial cash flow, bearing in mind the condition of the customer is also experiencing the same thing. through the instructions 
there (siinas.kemenperin.go.id.) [6][1]. This is done both for the internal company / in the area of the company / project also applied to outsiders who want to enter the company, including the entire fleet of ships that are in it also do the same thing [9][10][11]. The other side of management must do savings such as negotiating loans to banks, collecting receivables to customers as soon as possible, renegotiating debt problems to suppliers, maximizing bonds wisely, and also revising financial plans, also doing business survival by reducing margins, down payment systems, collaboration with actors, collaboration with vendors and suppliers with transparency management [11][12]. Manage information that is comunicated and updated news by maximizing online media, etc., maximizing video calls, charts, conferance zoom, seeking new opportunities during crises and after crises. Shifting outlook and capex and opex by submitting EOT, reviewing contacts, submitting claims, reviewing scope of work, revising contextual and limitation resources by issuing new policies based on existing regulations. Including conducting offshore onshore collaboration by means of conversion between sea, water, and land [3][16][17].

This was done for the survival of the company both during the covid pandemic period 19 and the period after the pandemic was completed [8][9]. In this case the product chain (goods and services) required the role of suppliers or distributors to distribute products produced by producers to consumers [13][15]. A producer can act / act as a consumer and vice versa, this can also be imitated at the corporate level, namely conversion between sea, water, and land as described above [14][15]. Macro-economics explains that economic changes that affect many communities, companies and markets can also be used to analyze the best ways to influence policy targets such as economic growth, price stability, labor and achieving a sustainable balance sheet [13][14][19]. Figure 1 below shows the macroeconomic cycle.

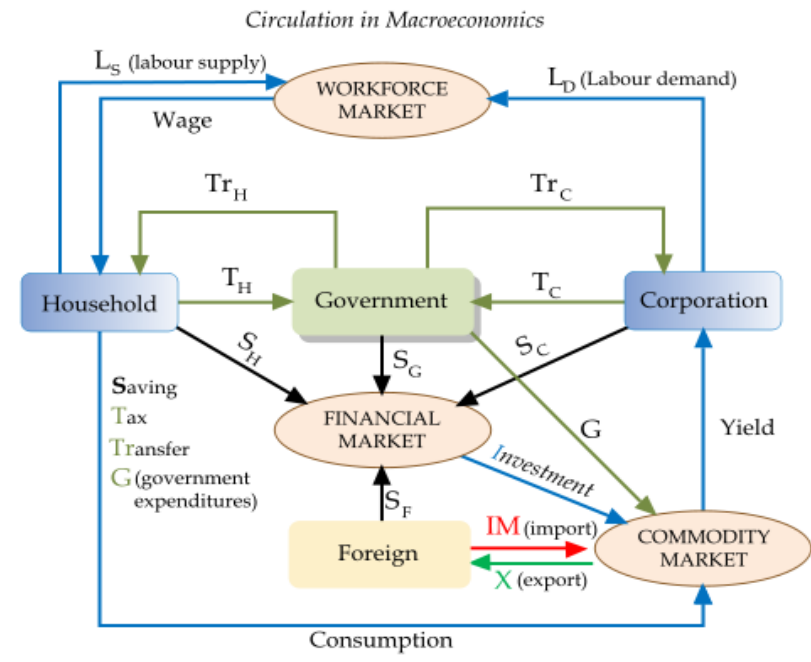

Figure 1. Macroeconomic Cycle [13].

Macroeconomics includes various concepts and variables, usually connected with the phenomenon of output, unemployment and inflation [13]. On the other hand, these topics are also very important for all economic agents including workers, consumers and producers. The covid pandemic 19 period, as now requires management to create macro measures and policies that make all stakeholders feel comfortable and safe [13][18].
Utilizing all available resources for the company's sustainability is one of them. Project management tools, project management people and project management execution, with the hope that this survival strategy will succeed, can get through this covid 19 pandemic well and the company can also go through the aftermath of this crisis as well [19][20].

\section{Materials and Methods}

This paper uses quantitative data analysis from various sources that can be used as a study to obtain a new analysis to be used as a solution to the completion steps or recommendations related to the covid pandemic 19 in relation to the maritime sector business [20][9][10]. The covid pandemic 19 disaster has made the economy unstable, all business sectors are running improperly, declining and getting worse [8][9]. Key sectors of global economic stability are exposed, food, agriculture, apparel, logistics, automotive, insurance, power plant, infrastructure, processing plant, financing, oil and gas, travel tourism, steel industries, minning industries, aerospace, defensive and maritime. For the infrastructure, oil and gas and power plant sectors, these three sectors have been very influential globally and suffered a severe blow plus the issuance of various regulations from the government that must be implemented immediately, while world market trends are increasingly uncertain [3][4]. This requires the existence of crisis management that can quickly give a positive reaction to all parties concerned and provide a sense of security through this pandemic and after the pandemic is over [3][4][7]. The incident above was made as material for analysis to make steps, business survival, awareness, information management; communication and updated news, to take steps to shift the outlook and capex and opex with references to both PP, Keppres, Perpres and other internal regulations [3][7].

The survival strategy by optimizing all available resources, resources related to the company's tools can be utilized as much as possible which can bring in new cash payments more quickly, such as receiving maintenance, repair [4]. Resources related to people must also be encouraged to exploit each other's potential, both in personnel and in groups. Providing training, becoming a resource, etc. according to the expertise. This is an effort to help minimize the company's tasks [4][3]. Management execution should also be used as a solution to be able to accelerate and shorten all practices of the company's tasks in order to obtain efficiency and reduce the company's burden [4][13]. Macro-economics explains that economic changes that affect many communities, companies and markets can also be used to analyze the best ways to influence policy targets such as economic growth, price stability, labor and achieving a sustainable balance sheet [13][14][15]. Macro-economics includes various concepts and variables, usually connected with the phenomenon of output, unemployment, and inflation [13]. The other side is also useful for all economic agents including workers, consumers, producers [13]. Negotiating and re-negotiating, speeding up the collection of receivables, making new financial resources from the use of existing resources in order to strengthen the company's cash flow is a step to save the company against the company's obligations on claims received and become the obligations of the company [13][1][3]. All of the above strategies must be able to be applied to companies without excessive turmoil, so this step requires good leadership [4][2]. All resource components can consciously unite in making joint steps to get through this crisis well [4][2]. 


\section{Results and Discussion}

The sudden emergence of the covid pandemic 19 and coupled with the issuance of regulations from the government which even rapidly with the progress of the covid 19 pandemic were evaluated hourly and day by day, the turmoil of the world market is rapidly changing, with a worsening trend, making all the sector is taking anticipatory steps so quickly[7][8]. Therefore, in this discussion, it is grouped into a number of large sectors that are dominantly affecting the state of the global economy, sectors that affect the domestic economy [9][10].

Maritime industry sector: In accordance with the Director General of Sea Transportation Circular, No.13 of 2020, dated 26 March 2020, concerning passenger restrictions on ships, logistics related to Covid 19, also law No.21 of 2020, dated 31 March 2020, regarding PSBB in the context of accelerating the handling of Covid 19[3][6], which was strengthened by Presidential Regulation No.11 in 2020, dated March 31, 2020, concerning the stimulation of public health emergencies regarding the Covid 19 outbreak[7], also the Minister of health No.9 in 2020, dated April 3, 2020, concerning the PSBB guidelines / Large-scale Social Restrictions[8], also Minister of Industry No. 7 of 2020, regarding guidelines for the submission of industrial activity permits in the Covid emergency period 19 and finally No, 16 of 2020 by the Director General of sea Transportation dated April 9 regarding the extension of the validity period of ILR and LSA certificates[6][7][8][9][10]. In response to this, all maritime sector actors must immediately form a team in the framework of implementation in the field, the issuance of various kinds of instructions bring different consequences in accordance with their respective fields [7][20]. For shipping companies, shipyards and other maritime sectors with the covid pandemic 19 disaster, this is a severe blow considering that with the implementation of this PSBB all activities must be diverted to areas that can quickly provide solutions, such as transportation of staples or even medical devices that are still allowed by the government, even many shipping schedules have been canceled, as happened in March - April 2020, 544 shipping schedules have been canceled from 1300 existing shipping schedules (intra-asia routes), cancellation of development work contract agreements ships, the decline in imports, etc[1][4][8][10]. Management of management both related to humans / workers, tools / tools and implementation of methods as a form of solution must be really good / not cause turmoil, besides that it also anticipates delays in order completion, which is caused maybe the arrival of material that is experiencing delays / longer or slower rhythm of work due to the application of covid prevention procedures in the field / project. For companies that have more material reserves or have already purchased material at the beginning of the budget, companies like this are not drastically affected because as long as the material is available the company can still work and bill to third parties. However, this also remains a high concern, because the end of the covid pandemic 19 period cannot be determined yet [16][18].

For service providers such as BKI, companies must really take into account the strength of good resources, involving human / employee management, tools / equipment, and execution of methods for dealing with the covid pandemic 19[4][9]. Professionals / experts in their fields must be given the freedom to utilize the available resources in the company, either in the form of transferring equipment functions or utilizing experts personally, such as doing repair / maintenance, receiving online traning services, making programs that can bring new profits quickly, even though the amount is small, tips like this should be spread by all employees who can do that[4][16]. There are many more tips for companies in dealing with the condition of the covid pandemic 19 , which is how the company can survive, can pay employees at least for the next few months as a short-term solution, the medium term is the end of 2020[4][17]. The company must be aware of its lack of achievement company achievements and must immediately determine the anticipatory steps of the worst possible and should layoff is the last action / solution [4][17].

World economic predictions related to the Covid 19 pandemic outbreak, which befell all sectors, such as the food sector, agriculture, apparel, logistics, and automotive with consideration of, the level of demand, fuel prices for the 4 April 2020 period, low levels of risk, global trade, and conditions the economies of both China, America and the economies of the European Union, which until now has not been said to improve[3][18]. Sector, insurance, power plant, infrastructure, processing plant, financing, are also no less sad as a result of falling oil prices and price volatility, the emergence of new businesses in the Covid 19 era, also decisions and agreements regarding world oil products, evaluations from the FED ( interst rate), investors entering and offering followed by the financial sector which is just beginning to grow[2][11]. Also the oil and gas sector, the tour and travel steel industries and minning industries where the sector sector, especially the oil and gas sector has not recovered, so this sector chose to act safely, Moreover, many countries, which have not fully opened themselves both from the domestic tour and travel sector, are also just a few countries that have just begun to open themselves and even certain sectors, such as only for domestic tourist destinations[11][12]. Aerospace, defensice, and maritime sectors, this sector is only to serve the logistics / staples of the community, and even then, only travel-travel pe government / appointed, also regarding the infrastructure and continuity of PSN. Such conditions trigger sectors, infrastructure, oil and gas, and power plants, to set safe strategies, especially to become a unit rate and supply stability [18][19].

The hallmark of the covid pandemic crisis in the year 2020, is different from the crisis / disaster from the previous remember, Uncertainty, no one can predict or see in the future when the end of this crisis is over[4][11][16]. Global impact that touches almost all sectors, and is directly related personally and family. Events that move quickly, with progress from day to day, with the situation constantly changing constantly and unprecedented, so that the lack of studies and references and is an extraordinary event both by the government, companies, and individuals [2][5]. This demands quickly to make policies, responses, and mitigations to counter these 19 impacts. Management policies must reach the infrastructure, work systems and engagement sectors that are demanded to be fast and appropriate. But it must not be quick to draw conclusions for a policy relating to third parties, for example regarding the actions of Force Majuere. This cannot be done just because of the covid 19 disaster, especially since Article 1338 of the Civil Code has clearly been regulated.

The oil and gas sector: The impacts of the PSPB / Social Distancing policy on upstream oil and gas activities include; Longer material transportation, especially material delivery from abroad, inspection of the performance of equipment, facilities, longer due to WFH and if necessary bring workers from abroad and within the country, mobilization of workers to the location is more difficult due to licensing and quarantine time, and the potential for 
overstaying. risks to safety, engineering productivity and construction are lower because of WFH, labor productivity decreases, limited number of personnel allowed to be on the project site, especially for offshore projects, manufacturing project activities are delayed or longer, and what needs to be anticipated is management approval licensing can take longer [2][17].

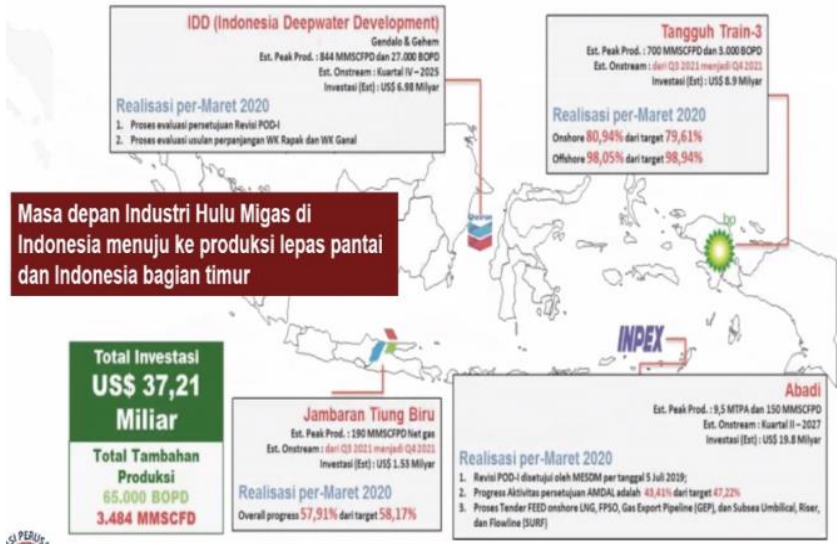

Figure 2. Project Strategic Nasional (Source: SKK Migas)

In figure 2, the condition of the covid pandemic 19 carries a large consequence on national strategic projects, which have an impact on the declining rate of economic growth and result in the achievement of predetermined achievements [2][17]. The number of offshore oil and gas facilities in Indonesia, as shown in the figure below.

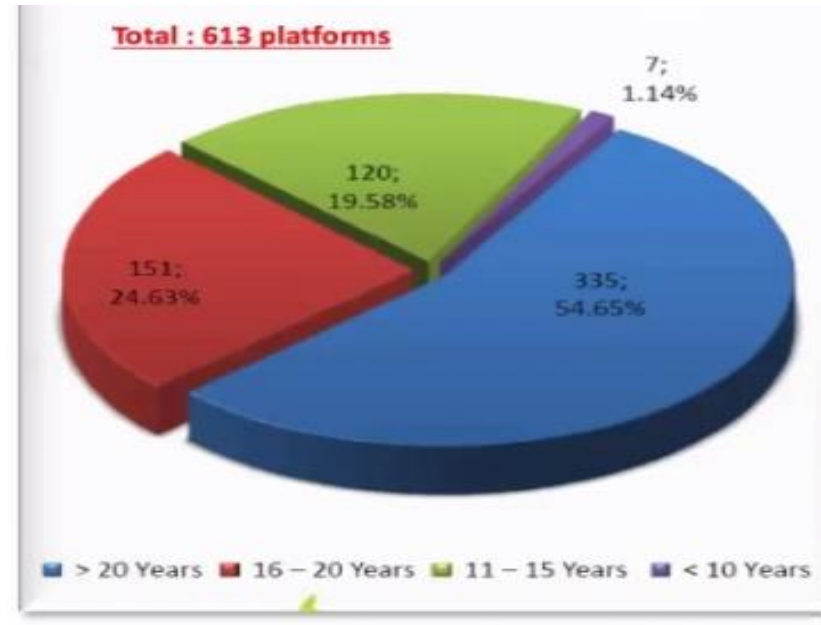

Figure 3. Platform Based On Year Build and Operated.( Source: SKK Migas

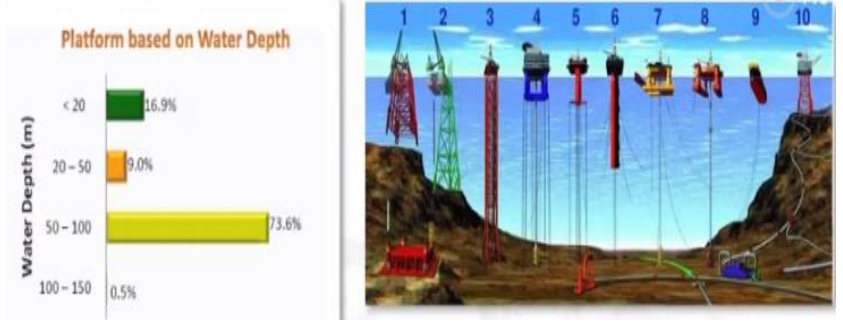

Figure 4. Platform Based on Water Depth

Table 1. List of FPSO facilities in Indonesia

\begin{tabular}{|c|c|c|c|c|c|c|c|c|}
\hline Name & $\begin{array}{l}\text { Pemilik } \\
\text { FPSO }\end{array}$ & Field Operator & $\begin{array}{l}\text { Lokasi } \\
\text { Produksi }\end{array}$ & $\begin{array}{l}\text { Kedalaman } \\
\text { Operasi }\end{array}$ & $\begin{array}{l}\text { Produksi } \\
\text { Minyak }\end{array}$ & $\begin{array}{l}\text { Produksi } \\
\text { Gas }\end{array}$ & $\begin{array}{l}\text { Kapasitas } \\
\text { Storage }\end{array}$ & Panjang \\
\hline Anda Natuna & Premier Oil & Premier Oil & Anoa Block A & 77 & 70 & 32 & 550 & 165 \\
\hline Belanak & $\begin{array}{l}\text { Conoco } \\
\text { Philips }\end{array}$ & Conoco Philips & $\begin{array}{l}\text { Belanak West } \\
\text { Natuna Block } \\
\text { B }\end{array}$ & 90 & 55 & 14 & 880 & 285 \\
\hline Brotojoyo & $\begin{array}{l}\text { Berlian Laju } \\
\text { Tanker (BLT) }\end{array}$ & $\begin{array}{l}\text { Pertamina/Petro } \\
\text { CHina }\end{array}$ & Salawati & N/A & 28 & NA & 400 & 202 \\
\hline $\begin{array}{l}\text { Kakap } \\
\text { Natuna }\end{array}$ & MODEC & Conoco Philips & Kakap KH & 88 & 25 & 25 & 760 & 284 \\
\hline $\begin{array}{l}\text { MVB Langsa } \\
\text { Venture }\end{array}$ & MODEC & Mitsui Oil & $\begin{array}{l}\text { Langsa Field } \\
\text { N. Sumatra }\end{array}$ & 100 & 15 & N/A & 270 & 170 \\
\hline $\begin{array}{l}\text { BW Joko } \\
\text { Tole }\end{array}$ & BW Offshore & Kangean Energy & $\begin{array}{l}\text { Terag Sirasun } \\
\text { Batur (TSB) }\end{array}$ & 90 & 7 & 340 & 200 & 253 \\
\hline $\begin{array}{l}\text { Sea Good } \\
101\end{array}$ & Apexindo & Santos & Oyong Field & 45 & 8 & NA & NA & 94 \\
\hline
\end{tabular}




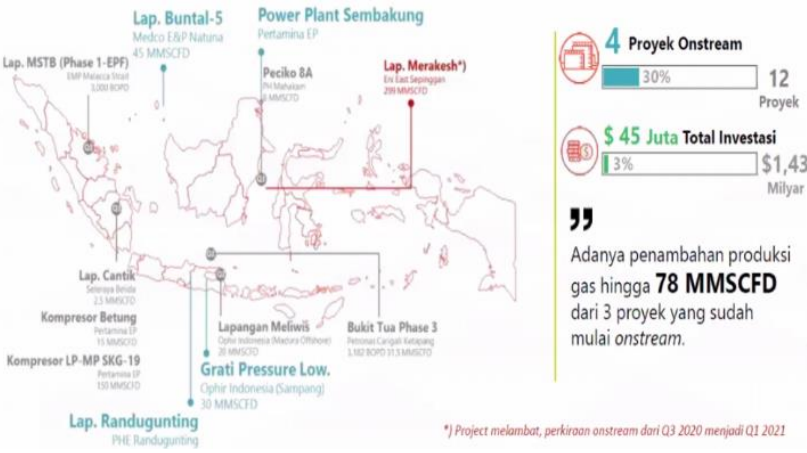

Figure 5. Project Onstream Kuartal I - 2020 (Source: SKK Migas) Prediction of the global economic situation and world oil prices, plus the situation of world trade will experience a recession, the EU predicts that Indonesia is one of the 3 countries experiencing growth above zero in 2020]2][17]. The IMF also predicts oil prices will remain below USS $40 /$ bbl by 2020, because the world has begun to lack storage for unsold oil[17]. With the end of the covid pandemic 19, oil will rise again in the range of USS45 / bbl in 2021, so oil prices are predicted to be stable for several years later around USS50 / bbl (the new normal) as shown in the chart below[2][17].

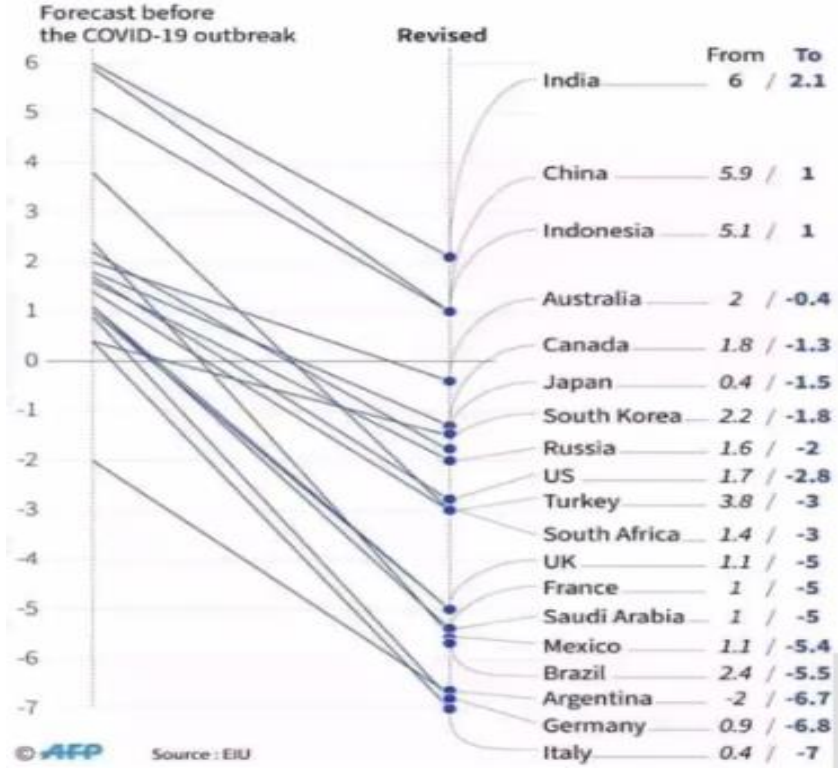

Figure 6. Revised Growth Forecast (Source: Economist Intelligence Unit for 2020)

The status of petroleum in Indonesia. Peak oil production was reached in 1977 and 1991 which was 1.7 million barrels / day, with recoverable oil reserves of 3.1 billion barrels, initial oil reserves (OOIP) of 87.0 billion barrels[2][17][. Also of 61.0 billion barrels is the remaining oil reserves that could not be extracted by conventional means. This will be taken $30 \%$ by using EOR technology which will produce 18.3 billion barrels, as in the graph below[2][16].

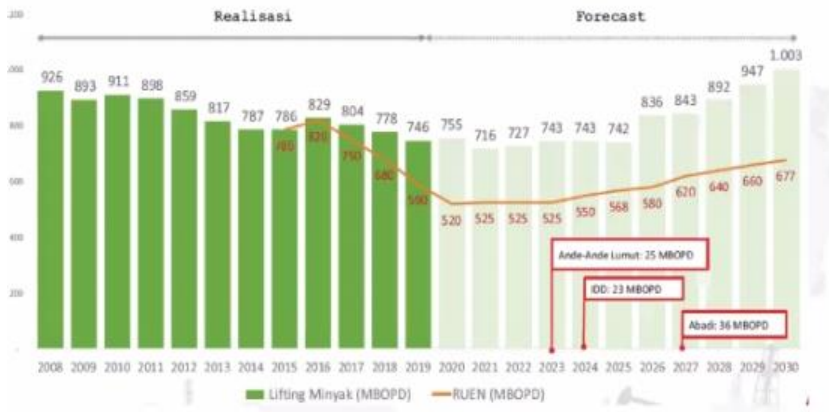

Figure 7. Petroleum in Indonesia (Source : SKK Migas, President Regulation No. 22/2017 RUEN)

If we look at the graph above, a new breakthrough is needed so that imports do not continue to experience an upward trend, which results in a burden on the Indonesian State Budget[2][17]. The status of Indonesian natural gas, it should be known that the value of Indonesia's natural gas production from $1963-2018$ is only around $80 \mathrm{TCF}$, and this is the peak production point in 2010 of $8.7 \mathrm{BCF} / \mathrm{day}$, with natural gas reserves found to be estimated 100TCF which means the remaining $20 \mathrm{TCF}$ that have not been utilized, also with natural gas reserves that have been found and not yet produced, estimated at $53 \mathrm{TCF}[2][17]$. This has become a mainstay of energy sources and export revenues for Indonesia, as shown in the graph below[2][17].

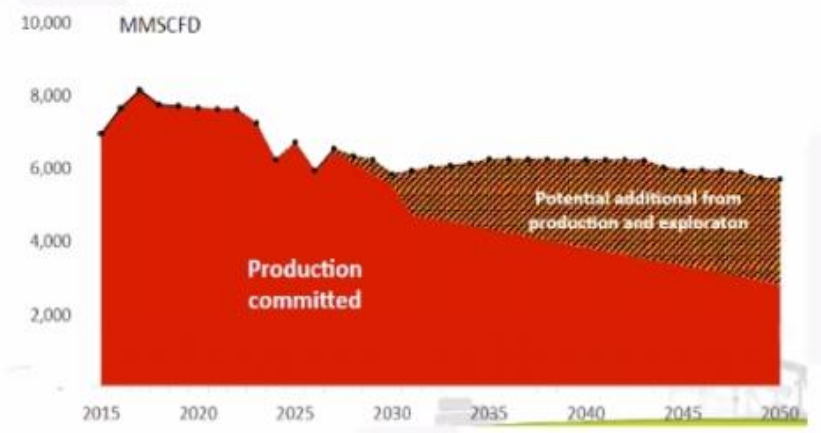

Figure 8. Status of Natural Gas in Indonesia (Source : SKK Migas, President Regulation No. 22/2017 RUEN)

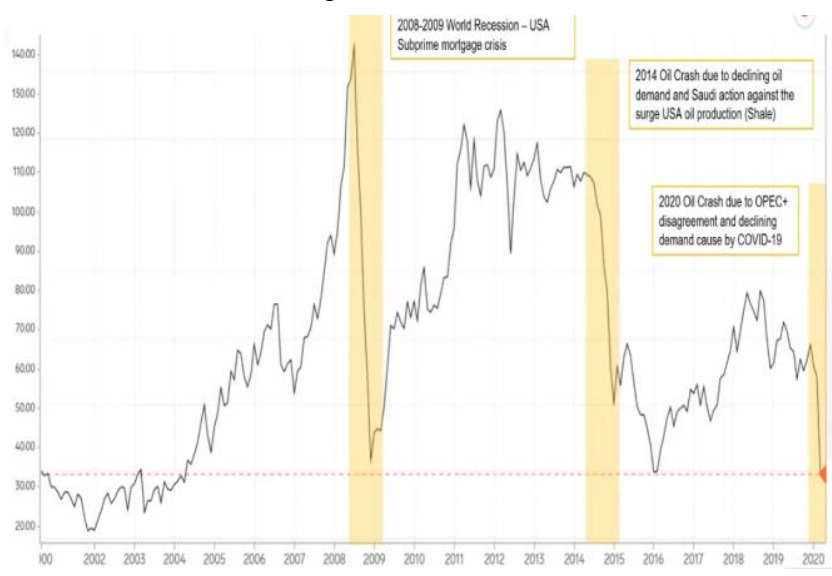

Figure 9. The Journey of Oil Prices in the years 2004-2020 (Source :Brent Price Index,2020) 


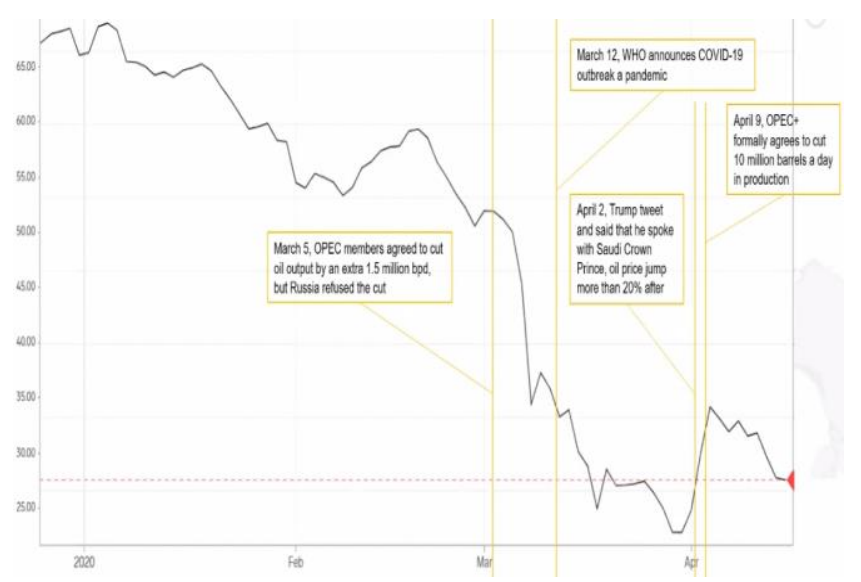

Figure 10. Fall in Oil Prices in 2020. (Source : Brent Price Index ,2020)

Deal with this incident which is usually done by oil companies is to do things that are often done in previous years such as in 2009 and 2014, such as; cutting CAPEX expenditures by $30 \%$ or more, renegotiating work contracts with supporting companies by $20 \%$ or more, acquisitions or mergers carried out by world oil companies, buyback shares, and utilizing their undervalued share prices, offering early retirement packages and layoffs, cutting unnecessary costs, especially the R\&D section, delaying non-care programs such as reducing emissions, carbon capture, reducing gas flares, and other environmental sustainability initiatives[2][16]. It is also important to reduce or delay dividends and invest in appropriate technology which can immediately reduce costs. For more details, the impact of the covid pandemic 19 can be seen in the upstream oil and gas industry sector, such as; operational activities, such as planned stutdown delays at Banyu Urip and Tangguh Fields, Well work and maintenance programs at CPL Petrochina OSES, Well P\&A activities at Conoco Philips, also delays of drilling and reworking activities and Well maintenance at EMP Malacca, Medco, Petrochina, etc. Also a decline in Outlook, a potential pullback from the Meraces project, and a decline in state revenues from USD 32 billion to USD 19 billion[2][16][17].

Shipping and Shipyard Sector: The company continues to run according to the instructions, but it is realized that the implementation has slowed down as a result of implementing the Covid Prevention Handling 19 protocol, because this applies to the company internally as well as to goods and people who enter the company / project location[1][10][19]. Work is carried out as scheduled, only in dealing with this pandemic period needs to be renegotiated regarding the worst possibility, so that companies can still make bills. Strengthening cash flow is done as a security measure for both parties, because it is not only our company that is affected but also customers and clients[1][10]. For companies that conduct material purcasing at the beginning of the fiscal year can still breathe freely because for the next few months can still do the work, so this helps the company to be able to do the bills, for example this is done by PT. ASS[1][10]I.

Insurance and QA Sector: In this case BKI, the response and mitigation of the impact of covid 19, as an effort by the company to ensure the health and safety of employees, in order to remain in good condition[4]. This is done thoroughly both on infrastructure, work systems, and engagemen[4][6]t. In practice it must contain what we call Agile Core Values which contain; unity (individual and team interactions over processes and tools), simpicity (working software over comprehensive documentation), transparency (customer collaboration over contract negotiation), and adaptability (responding to change over following a plan). a dissision in the implementation of both people and tools, which produces some replacess as a solution, method execussion which produces several tranning course schedules with several categories in the initial period of this pandemic. The above is done as a form of tips for the survival of the company in order to bring income quickly to help the company's financial condition[4][1][15]. In dealing with such situations, it is necessary to apply crisis management, so that the main things that must be prioritized are found, such as; Honesty and openness with the team and employees related to external and internal situations of the company, constant communication with the team and employees, forming a crisis team that is flexible in terms of its members and its movements follow the development of needs and field situations[4][1][14]. Intelligence team that monitors the external and internal situation of the company or project, and always be informed about the latest government policies, make scenario planning with some assumptions from normal to worst and strategies that need to be taken after the crisis is over, show empathy and sacrifice, especially to lower level workers, maintain good communication with external relations (suppliers, creditors, cliens, ... etc) that will help us in negotiations if needed, no one knows for sure when the covid pandemic 19 ends, companies will take long-term action in view of this uncertainty[4][1][10].The Government is expected to provide fiscal incentives, especially to national companies, in the form of tax breaks, small loans and others so that companies can survive to avoid layoffs and be able to rise again after going through this crisis, planned and long-term oil and gas projects, such as LNG Abadi-Masela, are likely to experience delays, but will continue and it is hoped that layoffs are the last solution taken, companies are expected to be better prepared if the economic situation and oil prices improve by focusing on employee training[4][1]. Also must always pay attention to global market trends bearing in mind that these conditions experience fluctuating changes that cause the maritime export-import sector to decline and some local maritime sectors to be corrected. For more details, we see the graph below, so tips and solutions are taken to be appropriate[4][1].

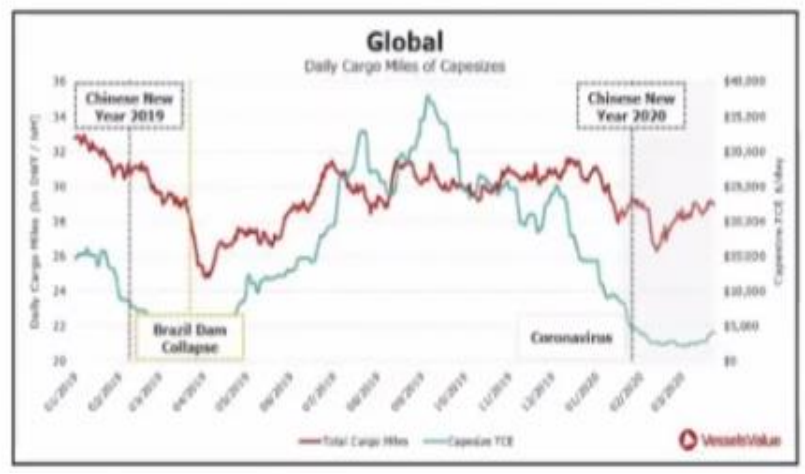

Figure 11. Global Daily Cargo Miles of Capesizes (Source : www.shiptechnology.com/features/impact-of-coronavirus-on-shipping/) 


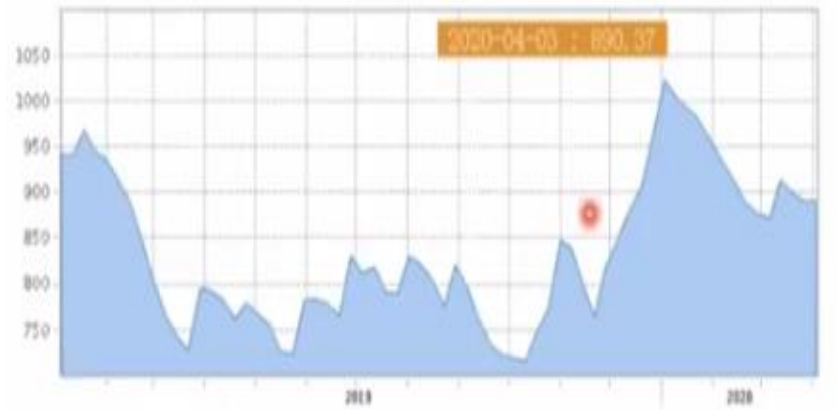

Figure 12. Shanghai Containerized Freight Index (Source : https://en.sse.net.cn/indices/scflnew.jsp)

According to the data above, the daily cargo demand market per day from early 2020 to March continues to decline to around \$2,000, although there was an increase at the end of March but has not shown a significant increase in daily cargo capsize, the Shanghai containerized freight index as a basis for trading prices Its main logistics transportation in Asia is still quite high at 890.37 compared to 2019 in the same month between 700 to 800 . Declining cargo volume, both in the impact of import exports such as China, declined by 14-18 percent and spread to the destination countries others, like Singapore and South Korea. Likewise for domestic cargoes, especially for cargo supporting export imports and national distribution, which fell 5-10 percent. (INSA) Carmelia Hartoto, 31 March 2020. Bank interest rates are still high for shipbuilding, a significant increase in the dollar exchange rate (which has an effect on production costs) in recent times amid the co-19 pandemic, making new shipbuilding has fallen dramatically due to hold or hold. canceled. Corona virus outbreaks or covid-19 have canceled 544 voyages out of a total of 1,300 Intra-Asia route voyages within 30 days of the Chinese New Year celebrations on January 25, 2020. According to SITC data and calculations, the average loss per ship reached USD 220,000 in total from Charter and bunker fees. Although production activities in China have now begun again with a controlled spread of the virus, a number of small-scale shipping companies in IntraAsia trade will experience financial difficulties in the coming months. (sea - intelligence consultant)[2][3][11][12].

\section{Conclusions and Suggestion}

In accordance with the procedures for handling the 19th pandemic countermeasure, the company took long-term action to take solutions to the company's survival. The government is expected to provide fiscal incentives, especially for national companies in the form of tax breaks, small loans and others so that companies can survive, avoid layoffs and rise again after going through this crisis. Make scenario planning with some assumptions from normal to worst and form a flexible crisis team in terms of its members and movements following the development of needs and situations in the field.

\section{5. acknowledgements}

In this regard, I would like to express my gratitude for the enlightenment, sharing of knowledge and the implementation of the 2020 maritime webinar seminar initiated by BKI Academy, the Indonesian National Association of Oil and Gas Companies, IATMARIN and PT. ASSI.

\section{REFERENCES}

[1] Anita Puji Utami, Dirut PT. Adiluhung Sarana Segara Indonesia, materi webinar maritim 20 april 2020.

[2] Arif Bijaksana Prawiranegara, BKI Academy,materi Webinar maritim 20 april 2020.

[3] Moshe Rizal Husein, Asosiasi perusahaan migas nasional indonesia, materi webinar maritim 20 april 2020

[4] Muhammad Ade Irfan, Project financing management, materi webinar maritime 20 april 2020

[5] SE. Dirjen Perhubungan laut nomor 13 tahun 2020, tentang pembatas penumpang kapal angkutan logistik terkait covid-19

[6] UU nomor 21 tahun 2020, tentang PSBB dalam rangka percepatan penanganan covid 19

[7] Perpres nomor 11 tahun 2020 tentang penetapan darurat kesehatan masyarakat covid 19

[8] Permen Kesehatan nomor 9 tahun 2020 tentang pedoman PSBB.

[9] Permen Perindustrian nomor 7 tahun 2020, tentang pedoman pengajuan ijin kegiatan industri dalam masa darurat covid 19.

[10]SE. Dirjen Perhubungan Laut nomor 16 tahun 2020, tentang perpanjangan masa berlaku sertifikat ILR, LSA

[11]Economic research monthly, economic update march, 2020

[12]Mc Kinsey, The hardest sector, march 25, 2020.

[13]Afandi. "Analisis Studi Kelayakan Investasi Pengembangan Usaha Distribusi PT. Aneka Andalan Karya"Fakultas Ekonomi Universitas Gunadarma

[14]Herry, B., \& N., Rahmi, H.(2008) “Analisis Keuntungan Usaha Dock Slipway Dan Dock Angkat Di Pelabuhan Perikanan Samudera Nizam Zachman Jakarta”Jurnal Saintek Perikanan Jurusan Perikanan Fakultas Perikanan dan Ilmu Kelautan Universitas Diponegoro Vol. 3, No. 2, : 74 81

[15]Imas, D.,W., \& Dewi, R.. “Analisis Faktor-Faktor Yang Mempengaruhi Arah Manajemenlaba (Studi Pada Perusahaan Manufaktur Yang Terdaftar Di Bei 2009-2013)" Program Studi Akuntansi, Fakultas Ekonomi, Universitas Atma Jaya Yogyakarta

[16]Brent price index, $2020 \mathrm{https} / / /$ tradingeconomics.com/commodity/brentcrude-oil

[17]SKK migas, president regulation, no. 22/2017 RUEN. https://www.eria.org/uploads/media/10.ERIA-RPRFY2017_09_Chapter_2_2.Indonesia.pdf

[18]Wood, G.,M.. (2014). Worldwide Survey of Floating Production, Storage and Offloading (FPSO) Unit. Poster NO. 115.

[19]www.siinas.kemenperin.go.id tentang juklat penangan covid 19 pada perusahaan, https://kemenperin.go.id/artikel/21679/Kemenperin-PastikanKegiatan-Industri-dan-Protokol-Pencegahan-Covid-19-Dapat-BerjalanBeriringan

[20]Adele, B.(2020). “The impact of Covid-19 on the global shipping sector: part 2 , silver linings" www.ship-technology.com/features/impact-ofcoronavirus-on-shipping/ 